\title{
Křesłanská sociální práce v Polsku, Idea a praxe
} Tadeusz Kamiński

Článek nejprve předkládá úvahy na téma podstaty křestanské sociální práce. Poté následujíprávnípodklady sociálnípráce v Polsku, požadavkyna kandidáty tohoto povolání a typická místa zaměstnání polských sociálních pracovníků. V poslední části se autor zabývá otázkou křestanské orientace polských sociálních pracovníků, pokusy o jejich formaci v křestanském duchu a představuje dobrovolníky $\vee$ církevních organizacích, kteři se zabývají pomocí potřebným jako neformální sociální pracovníci.

\section{Co je to křest́anská sociální práce?}

Než odpovíme na otázku, čím je křest'anská sociální práce, pokusíme se upřesnit, čím je sociální práce obecně. V nejzákladnějším pojetí je sociální práce formou služby osobám, které se nacházejí v těžké životní situaci a potřebují podporu. Může být vykonávána bud' jako zaměstnání, nebo dobrovolně, a jejím cílem je dosáhnout pozitivní změny v životních podmínkách př́ijemce pomoci (Haines 1978: 10). Sociální práce jako zaměstnání vyžaduje speciální znalosti, úsilí o realizaci hodnot a použití odpovídajících metod a technik činnosti. Sociální pracovníci jako profesionálové pracují ve jménu společnosti a jsou spojeni s konkrétními společenskými institucemi (Bartlett 1976: 231-236). V širším slova smyslu znamená sociální práce veškerou činnost, která si klade za cíl podporu potřebných a zahájení pozitivních společenských změn, vedoucích ke zlepšení životních podmínek a k tomu, aby se všichni členové společnosti mohli uplatnit. V takovém pojetí je sociální prací též činnost dobrovolníků $\mathrm{v}$ charitativních organizacích, pokud slouží pomoci při řešení problémů jednotlivců, rodin a společenských skupin (Kamiński 2004: 8).

Jako profesionální činnost se sociální práce objevila teprve na přelomu 19. a 20. stol. Dřive byla pomoc potřebným poskytována především církví, a proto byla ze své podstaty křest'anská. Počátky organizované charitativní činnosti jsou spojeny s povoláním sedmi jáhnů v první křest'anské komunitě v Jeruzalémě (Mette 1991: 258). Rozvoj této činnosti vytvořil svým způsobem monopol církve v oblasti organizování pomoci. Tento monopol se otřásl teprve v 19. stol., kdy masově vznikala dobročinná sdružení na různých ideových základech. V souvislosti se stále větší angažovaností státu v sociální sféře se objevily sociální služby organizované státem, jejichž hlavními představiteli se stali sociální pracovníci.

Ptát se na křest'anský charakter současné sociální práce je velice opodstatněné, když vezmeme $\mathrm{v}$ úvahu důležité změny, $\mathrm{k}$ nimž došlo za posledních více než 100 let. V některých zemích totiž byly v průběhu 20. století církevní organizace se svojí charitativní činností vytlačeny úplně na okraj. Organizátorem sociální pomoci se stal stát a jejími realizátory placení sociální pracovníci s odpovídající přípravou. Je to důsledek na jedné straně už vzpomenuté expanze státu v sociální sféře, na druhé straně však také důsledek laicizace společnosti, zejména v západní Evropě. Charitativní činnost vyžaduje spojení věřících s církví a ochotu podporovat její aktivity i finančně. Ve státech s rozvětvenými sociálními systémy, které jsou zároveň i sekularizovanými společnostmi, značně poklesla ochota k osobní nebo finanční angažovanosti. Není 
proto náhodou, že o křest́anské sociální práci se výrazně a oficiálně mluvilo (a mluví) prakticky jen v Německu a mimo Evropu snad pouze v USA.

V př́ipadě Německa je záležitost jasná, když vezmeme v úvahu tamní chápání zásady subsidiarity, které umožnilo náboženským organizacím, zejména katolické Caritas a evangelické Diakonii, rozvinout velmi širokou aktivitu ve sféře sociálních služeb a v důsledku toho zaměstnávat profesionální sociální pracovníky. Ve Spojených státech naopak navzdory oficiální odluce církve od státu jednotlivé náboženské denominace nadále vykonávaly a vykonávají sociální práci v širokém rozsahu. Do r. 1966 však nemohly být financovány z veřejných fondů. Situaci změnily teprve reformy systému sociální pomoci, díky nimž sociální programy realizované přes tzv. Faith Based Organisations mohou být dotovány v rámci právní regulace zvané Charitable choice (Sherwood 2000).

Chceme-li definovat, čím je křest́anská sociální práce, je vhodné sáhnout k textům vynikajícího německého teoretika církevní sociální aktivity Richarda Völkla. V textu věnovaném podstatným rozdílům v definicích Völkl (1987: 158-167) obrací nejprve pozornost k faktu, že termín „sociální práce” definitivně nahradil takový pojem jako „péče” (,Fürsorge”) a také „,sociální péče” („Wohlfahrtspflege”), které spíše zdưrazňují patriarchální nebo též mateřsko-pečovatelskou "starostlivost”, nebo "dohled a péči”, než pomoc vedoucí k samostatnému a zodpovědnému životu. Aby sociální práce byla křest'anská, je podle Völkla nutné její zakořenění ve víře a zaměření samotného sociálního pracovníka na realizaci přikázání lásky k bližnímu. Křest́anská sociální práce je tedy následováním Krista v jeho službě lidem potřebujícím pomoc a spočívá nejen na uspokojení nezbytných životních potřeb, ale též - a možná především - na zaměření člověka ke spáse. Tak tedy název „křest'anská” si zaslouží ta sociální práce, která když vezmeme v úvahu výše vyjmenované aspekty - je realizována křest'any a v křest́anském duchu. Völkl mluví rovněž o „církevní" sociální práci, což je taková, která se orientuje na církevní struktury, začíná u farností a pokračuje přes diecézi až ke všeobecné církvi. Jedná se tedy o sociální práci realizovanou církevními institucemi a organizacemi a církevním personálem.

Na skutečnost, že nelze ztotožňovat církevní sociální práci a křest́anskou sociální práci, obrací také pozornost Vicki Northernová (2009: 267). Ukazuje, že křest'anská sociální práce je spojena s pokusem spojit víru a světový názor s profesionální praxí a je druhem sociální služby plynoucí z Božího povolání ke službě potřebným. „Křest'anskost” sociální práce se proto netýká podstaty vykonávané práce, ale jejího podmětného aspektu: kdo, s jakou motivací a jakým způsobem tuto práci vykonává. V praxi to bývá často tak, že sociální pracovníci, kteř́ jsou křest'any, konají svou praxi ve světských institucích, zatímco sociální pracovníci, angažovaní v církevních zařízeních, nejsou křest'any. $V$ prvním případě bychom mohli hovořit o křest'anské sociální práci, v druhém o církevní sociální práci. Podobně jako u Völkla tedy závěr zní: Křestáanská sociální práce je sociální prací vykonávanou uvědomělými křest'any. Církevní sociální práce je prací vykonávanou v církevních institucích. V tomto kontextu se vnucuje otázka, jestli by nebylo lépe mluvit o křest'anských sociálních pracovnících a nikoli o křest’anské sociální práci? To je dobré téma k hlubším úvahám.

Když mluvíme o křest'anské sociální práci, musíme ještě vzpomenout profesní přípravu osob, jež by ji chtěly vykonávat v křest'anském duchu. Křest'anský sociální pracovník si musí být vědom své opravdové motivace a sepětí své práce s výzvou k vydávání svědectví o své víre. Proto je nezbytné zapojit do procesu formace sociálních pracovníků prvky praktické teologie. Dobrým příkladem tady může být vědecká disciplína, známá pod německým názvem "Caritaswissenschaft".

Caritaswissenschaft je odpovědí na potřebu systematické a ve značném stupni i speciální vědecké reflexe nad principy a metodami charitativní práce. Tato reflexe měla samozřejmě již mnohem dříve své místo $\mathrm{v}$ rámci pastorální teologie a právě na jejím základě se vyvinula disciplína, zvaná Caritaswissenschaft. Své institucionální vyjádření nalezla v roce 1925, kdy na teologické fakultě Univerzity Alberta Ludwiga ve Freiburgu im Breisgau vznikl Institut für 
Caritaswissenschaft. Tento institut se stal důležitým centrem bádání nad podstatou, základy a cílem charitativní práce, označené právě též jako křest'anská sociální práce. Aktivity v něm realizované potvrzují jak silné spojení sociální angažovanosti křest'anů s vírou, tak i potřebu církevního smýšlení u osob, které se této službě věnují.

Jako vědecká disciplína náleží Caritaswissenschaft do praktické teologie, ale je silně spjata s křest’anskými společenskými naukami. Když ji její vynikající představitel H. Pompey (1994: 51) definoval, tvrdil, že tato disciplína čerpá jak z výsledků teologického bádání, tak i z různých nauk o člověku, zejména z medicíny, psychologie, sociologie a sociální pedagogiky. V centru bádání Caritaswissenschaft stojí vždycky nejdříve trpící člověk, potřebující pomoc, a také ten, kdo touto pomocí svědčí, jakož i celé společenství církve se svou povinností sociálně charitativní služby. Formace křest'anských sociálních pracovníků, zvláště těch, kteří nemají za sebou kurs teologie, může probíhat v podobě mimodiplomových studií, školení nebo dokonce rekolekcí.

\section{Sociální práce v Polsku}

Sociální práce, chápaná jako pomoc osobám potřebujícím podporu, má v Polsku dosti dlouhou tradici, srovnatelnou s jinými zeměmi. První pečovatelské instituce se objevily na počátku 12. století, a byly samozřejmě úzce spojeny s církví. Církev se věnovala této činnosti i v následujících staletích, zvlášt' aktivní byly v tomto směru řeholní komunity. Sociální práce jako zaměstnání (i když se to ještě tak nenazývalo) se objevila oficiálně ve 20. letech 20. století. Aktivitu v této oblasti upravoval zákon o sociální péči ze srpna roku 1923. Systematické a programové vzdělávání $\mathrm{k}$ této práci započalo v roce 1925. V době komunistických vlád (po roce 1945) bylo nejprve řečeno, že činnost tohoto druhu je zbytečná a přestalo i vzdělávání v tomto oboru. Roku 1959 byli však sociální pečovatelé znovu povoláni a rokem 1966 zahájily svou činnost školy pro jejich přípravu. V té době bylo také oficiálně uznáno zaměstnání sociálního pracovníka. V 70. letech 20. stol. byla sociální práce v Polsku úzce propojena se zdravotnictvím a jejími adresáty se staly hlavně starší, nemocné a nesvéprávné osoby. Sociální pracovníci pracovali v tzv. střediscích sociálního pečovatele, která byla umístěna na poliklinikách (zdravotních střediscích). Převážná většina tehdejších sociálních pracovníků však postrádala odpovídající odbornou kvalifikaci, často se jednalo o zcela náhodné osoby. Po převratu roku 1989 získala sociální práce zvláštní význam, jako důležitý nástroj mírnění negativních účinků společenské transformace (Zasada-Chorab 2004: 34-66). Začal se také klást důraz na formaci profesionáli̊ v oboru sociální práce, což našlo své vyjádření v zákonu o sociální pomoci, který byl schválen v listopadu roku 1990.

V současné době statut sociální práce v Polsku upravuje zákon o sociální pomoci z 12. března 2004. V souladu s jeho předpisy je sociální práce zaměstnáním, které má za úkol pomáhat jednotlivcům i rodinám dosahovat nebo posilovat schopnosti k fungování ve společnosti plněním odpovídajících společenských úkolů a vytvářet příznivé podmínky k dosažení tohoto cíle. Oficiálně je proto sociální práce v Polsku zaměstnáním a je to tzv. regulované zaměstnání. Znamená to, že odpovídající státní předpisy dosti přesně určují, jaké podmínky nutno splnit, aby bylo možné toto zaměstnání vykonávat. Všichni, kteří vykonávají podobnou nebo i tutéž činnost, ale nesplňují formální kritéria, nejsou nazýváni sociálními pracovníky a jejich práce ve formálním slova smyslu není sociální prací.

Úpravy týkající se oprávnění k výkonu povolání sociálního pracovníka prošly v posledních dvaceti letech postupným vývojem. Původně stačil diplom získaný na škole pracovníků sociálních služeb v pomaturitním studiu. Nyní je snaha, aby se sociální pracovníci prokazovali vysokoškolským vzděláním. 
Sociálním pracovníkem se tedy může stát osoba, která splňuje jednu z níže uvedených podmínek:

- vlastní diplom ukončení kolegia pracovníků sociálních služeb (tato kolegia probíhají pod patronátem vysokých škol a dávají možnost získat licenciát)

- ukončila vysokoškolské studium v oboru sociální práce (tento obor byl zaveden roku 2006)

- do 31. prosince roku 2013 ukončila vysokoškolské studium se specializací, která připravuje $\mathrm{k}$ výkonu povolání sociálního pracovníka $\mathrm{v}$ jednom $\mathrm{z}$ těchto oborů:

a) pedagogika

b) speciální pedagogika

c) politologie

d) sociální politika

e) psychologie

f) sociologie

g) věda o rodině

Zákon o sociální pomoci stanoví, že sociální pracovníky zaměstnávají především instituce veřejné sociální péče. Proto také naprostá většina polských sociálních pracovníků vykonává svou práci ve střediscích sociální pomoci. Tato střediska existují v každé obci. Kromě toho sociální pracovníky zaměstnávají okresní střediska pomoci rodině. V souladu se zákonem o sociální pomoci mohou sociální pracovníky zaměstnávat $\mathrm{i}$ jiné instituce, $\mathrm{v}$ nichž jsou plněny úkoly z rezortu sociální pomoci. Do těchto institucí zákon řadí instituce trhu práce, nemocnice, pečovatelsko-výchovné ústavy a trestanecká zařízení. Jmenovány jsou také nestátní instituce jako fundace, sdružení, církevní organizace. $V$ mnoha zařízeních tohoto typu skutečně pracují sociální pracovníci, ale jejich statut je nejasný. Např́ílad sociální pracovník v nemocnici je pracovníkem zdravotnictví a ne sociální pomoci, což znamená, že nemůže využívat všech předpisů, které se týkají pracovníků sociální pomoci.

Zákon o sociální pomoci vyjmenovává též hlavní úkoly, jaké stojí před sociálními pracovníky. Nejdůležitějším, ale ne jediným, je samozřejmě sociální práce. Kromě ní se mají sociální pracovníci zabývat také péči o poskytování peněžité nebo věcné pomoci, poradenstvím, pobídkou ke svépomoci, spoluprací s jinými specialisty a iniciativami nových řešení $v$ rezortu sociální pomoci. Od sociálních pracovníkủ se očekává, že se budou řídit zásadami profesionální etiky, což jsou zejména: důstojnost druhého člověka, profesní tajemství, odmítání diskriminace. Zákon také ukládá sociálním pracovníkům stálé zvyšování profesní kvalifikace.

\section{Existuje v Polsku křest'anská sociální práce?}

Odpověd' na takto položenou otázku je těžká a složitá. Nejprve je nutno říct, že ani mezi praktiky sociální práce, ani mezi jejími teoretiky neexistuje takový pojem jako křest́anská sociální práce. Oficiálně práce sociálního pracovníka není žádným zpưsobem spjata s duchov- 
ním rozměrem, s křest'anskou inspirací. V Polsku není žádné sdružení sociálních pracovníků, které by mělo jednoznačně křest́anskou orientaci. Faktem ale je, že Celopolské konference sociálních pracovníků, organizované od roku 2002, se konají v klášterním komplexu na Jasné hoře v Čenstochové, čili ve svatyni, která je pro polské katolíky nejdůležitější. Nejsou to ale podle intencí organizátorů konference „katolických" nebo „křest'anských” sociálních pracovníků, mají otevřený charakter. Každého roku se jich účastní do 300 osob, důležitou součástí programu je mše svatá na úmysl sociálních pracovníků sloužená v jasnohorské kapli.

Nedostatek jakéhokoliv specificky křest'anského zaměření polské sociální práce je viditelný $\mathrm{už} \mathrm{v}$ etapě formace $\mathrm{k}$ tomuto povolání. Jak bylo už výše vzpomenuto, $\mathrm{v}$ katalogu studijních disciplín, připravujících $\mathrm{k}$ profesi sociálního pracovníka, se nenachází teologie. Ale i kdyby byla jmenována, tak v Polsku neexistuje subdisciplína, která by odpovídala Caritaswissenschaft. Jsou sice někteří teologové, kteří se specializují na charitativní činnost církve $\mathrm{v}$ rámci pastorální teologie nebo ve spojení s naukami o rodině, ale je těžké hovořit o nějaké formalizaci nebo institucionalizaci této specializace. Studijní program „vědy o rodině” na některých učilištích v Polsku má však ve skutečnosti dosti silný křest'anský profil a i tam, kde byla zavedena specializace $\mathrm{k}$ př́ípravě sociálního pracovníka, je vzdělávání $\mathrm{v}$ tomto oboru takto zaměřené.

Zajímavým př́padem je studium sociální práce Caritas na Univerzitě kardinála Stefana Wyszyńského ve Varšavě, které zde probíhá od roku 1995. Studium, které připravuje pro povolání sociálního pracovníka, probíhá $\mathrm{v}$ rámci studia politologie. Kromě závazných politologických disciplín nabízí i takové, jejichž cílem je dát křest́anský profil budoucím sociálním pracovníkům. V programu jsou např. historie dobročinnosti a základy charitativní činnosti církve. Absolventi tohoto typu studia získávají státní oprávnění $\mathrm{k}$ výkonu profese sociálního pracovníka. Toto oprávnění získávají též absolventi specializace sociální práce ve studijním oboru pedagogika na Křestáanské teologické akademii ve Varšavě. Na teologické fakultě Univerzity Mikolaje Kopernika v Toruni je zřízeno od roku 2006 magisterské teologické studium pod názvem „sociální práce Caritas”. Jde o teologické studium v plném slova smyslu, obohacené však o předměty z rezortu sociální práce, sociální pomoci a sociální politiky. Ve světle aktuálních závazných státních předpisů však absolventi teologického studia nejsou oprávněni vykonávat zaměstnání sociálního pracovníka ve veřejných institucích sociální pomoci. Jejich znalostí a dovedností mohou využívat pouze církevní organizace a to jedině tam, kde není požadována kvalifikace sociálního pracovníka.

Jak vyplývá z výše předložených analýz, rozhodující většina polských sociálních pracovníků nebyla $\mathrm{v}$ průběhu svého vzdělávání formována $\mathrm{v}$ křest́anském duchu. Ale podle statistik je možno očekávat $\mathrm{v}$ takové zemi, jakou je Polsko, kde drtivou většinu společnosti tvoří lidé pokřtění v katolické církvi, v praktické činnosti sociálních pracovníků křestáanský postoj. Zdá se tedy, že není důvod, proč by se měli v tomto ohledu sociální pracovníci lišit od ostatní společnosti. Ale potvrzují tyto předpoklady sociologické výzkumy?

Pokud chápeme mezilidskou solidaritu a lásku k bližnímu jako důležité ukazatele křest'anské orientace sociálních pracovníků, tak z výzkumů Anny Olechové (2006: 74-76) vyplývá, že solidarita chápaná jako pocit odpovědnosti za osud druhého člověka se v principu neobjevuje jako důležitý motiv činnosti. Tyto hodnoty jsou chápány spíše jako výzva ke spolupráci s jinými sociálními pracovníky. Podobně i láska k bližnímu je zřídkakdy chápána jako přikázání úzce spojené s podstatou sociální práce. Nejčastěji sociální pracovníci tvrdí, že není možné milovat všechny a pomáhat jim nezávisle na sympatiích, které mají či nemají vůči jiným lidem. To tedy znamená, že láska $\mathrm{k}$ bližnímu není pro sociální pracovníky postojem vưči druhému člověku, ale spíše projevem konkrétní sympatie či antipatie. Je-li možno dopídit se nějakého akceptování hodnot spojených s křestanstvím, tak je to důstojnost. Sociální pracovníci se všeobecně shodují, že př́ijemci pomoci si zaslouží úctu, vyplývající z uznání jejich důstojnosti (Olechová 2006: 61). 
Výsledky výzkumů potvrzují - jak se zdá - že sociální práce v Polsku, ta profesní, realizovaná v rámci veřejné sociální pomoci, má sekulární charakter. Sociální pracovníci jsou ve své práci zaměřeni spíše humanitárně než nábožensky. V denní praxi sociálních pracovníků převládá byrokratická a organizační aktivita. Chybí zde místo na hlubší kontakt s klienty, při kterém by se mohlo projevit duchovnější (spíše křest'anštější) zaměření sociálního pracovníka. Často je možno slyšet v Polsku hlasy, že stupeň byrokratizace sociální pomoci je tak obrovský, že se sociálním pracovníkům nedostává času na vlastní sociální práci. Celá činnost se točí kolem finančních záležitostí. Zdá se mi dokonce, že ve sféře veřejné sociální pomoci by byla jakákoliv manifestace náboženského přesvědčení a náboženské motivace posuzována velmi nepříznivě. Bylo by to špatně chápáno nejen představenými a spolupracovníky, ale zajisté i mnohými klienty.

Tyto výzkumy se týkají pracovníků veřejné sociální pomoci. Netýkají se osob, zaměstnaných jako sociální pracovníci v církevních zařízeních. Neposkytují proto celistvý obraz situace. Možno tedy přijmout jako předpoklad, že alespoň sociální pracovníci v církevních institucích se řídí křest́anskou motivací a snaží se konat svou práci ve shodě se svým náboenským přesvědčením. Tento předpoklad však ještě čeká na svoji empirickou verifikaci.

Více můžeme říci na téma motivace a postojů těch osob, které se angažují jako dobrovolníci v církevních institucích. Nejsou oficiálně uznáni jako sociální pracovníci, ale označováni jako dobrovolníci, spolupracovníci nebo charitativní pracovníci. Jejich aktivita však může být v mnoha případech chápána jako výkon neformální sociální práce. Takových dobrovolníků, pracujících zejména v rámci farních Caritas, ale i v jiných organizačních strukturách, je v Polsku kolem 100 tisíc. Značná část jich se bezprostředně stýká s lidskou bídou, neštěstím, nemocí, nesvéprávností. Nejsou omezeni byrokracií, mají větší možnosti praktikovat to, co jsme pojmenovali jako křest'anskou sociální práci.

Dosud nejzávažnější výzkumy na téma farních dobrovolníků byly provedeny v krakovské arcidiecézi kolektivem sociologů z Jagellonské univerzity v Krakově (Bocheńska-Seweryn, Kluzowa 2001). Tyto výzkumy ukázaly, że motivy stricte náboženské („Snaha realizovat přikázání evangelií") se projevily u sotva 8,7 \% respondentů. Je ale možné, že mnoho dobrovolníků chápe svoji aktivitu v životě farnosti (a potažmo v charitativní službě) jako samozřejmou součást víry, jež nevyžaduje žádnou deklaraci. Obecně chápaná ochota pomoci potřebným, deklarovaná jako motiv charitativní aktivity 62,5 procenty dotázaných, může znamenat rozumění pomoci jiným právě jako př́ikaz víry.

Ve vztahu k dobrovolníkům farních charitativních skupin existuje také mnoho možností, jak povzbuzovat a rozvíjet jejich křest'anskou motivaci. Tomu slouží speciální rekolekce, měsíční formační setkání, kursy pro lídry charitativních kolektivů, každoroční slavnosti Týdne milosrdenství. Jsou též organizovány kongresy, sympozia, speciální školení (Przygoda 2004: 391). V tomto smyslu je snadnější dbát o jejich adekvátní duchovní formaci.

\section{Shrnutí}

Jak vyplývá z výše představeného textu, pojem křest’anské sociální práce oficiálně nefunguje v polské skutečnosti ani ve vztahu ke každodenní praxi, ani v teoretických analýzách z této oblasti. Sociální pracovník má být profesionálem, dobrým sociálním pracovníkem a žádný jiný přívlastek není pro jeho označení nutný. Jistě jsou ale mezi profesionálními sociálními pracovníky lidé, kteří svoji práci spojují nějakým způsobem s povoláním ke službě chápané křest́ansky. Typicky křest'anskou motivaci lze však očekávat od osob zapojených do charitativních iniciativ církve. V rozhodující většině případů však tyto osoby nejsou uznávány za sociální pracovníky. Ve vztahu k činnosti organizované církevními institucemi se také spíše 
neužívá, než užívá takových pojmů, jako křest'anská nebo církevní sociální práce. Je to prostě charitativní činnost a pouze v tomto kontextu může mít i křest'anské konotace.

\title{
Literatura
}

Bartlett H.M. (1976), Grundlagen beruflicher Sozialarbeit, Lambertus Verlag: Freiburg i. Br. Bocheńska-Seweryn M., Kluzowa K. (2001), Moływy i formy pracy członków parafialnych zespołów charytatywnych, „Roczniki Naukowe Caritas” vol. 5.

Haines J. (1978), Interventiosprozesse in der sozialen Arbeit, Lambertus Verlag: Freiburg i.Br. Kamiński T. (2004), Praca socjalna i charytatywna, Wydawnictwo UKSW: Warszawa.

Mette N. (1991), Caritas: Praktisch-systematisch, w: P. Eicher (Hrsg.), Neves Handbuch theologischer Grundbegriffe, Kösel-Verlag: München.

Northern V.M. (2009), Social Workers in Congregational Contexts, "Social Work \& Christianity" vol. 36, No. 3.

Pompey H. (1994), Caritas, "Christliches ABC - Heute und Morgen", Heft 4.

Przygoda W. (2004), Posługa charyłatywna Kościoła w Polsce, Wydawnictwo KUL: Lublin.

Sherwood D. (2000), Charitable choice: Still an opportunity and challenge for Christians in social work, "Social Work \& Christianity" vol. 27, No. 2.

Völkl R. (1987), Nächstenliebe - Die Summe der christlichen Religion?, Lambertus Verlag: Freiburg i.Br. Zasada-Chorab A. (2004), Kształtowanie się zawodu pracownika socjalnego w Polsce, Centrum AV: Częstochowa.

\begin{abstract}
:
The artical presents considerations on the theme of the nature of Christian social work. Then it follows with the legislation of social work in Poland as well as the requirements of this occupation and typical emloyement of Polish social workers. In the last part the author adresses Christian orientation of Polish social workers, their attemps of formation in Christian spirit and presents volunteers in charitable organisations, who care for the disadvantaged as the informal social workers.
\end{abstract}

Key words: volunteering, Christian social work, social worker, social work, Poland 